\title{
STRATEGIES OF NATIONAL LITHUANIAN COMPANIES TO ENTER INTERNATIONAL MARKETS
}

\author{
Milda Matulaityte-Feldhausen ${ }^{1}$, Romualdas Ginevicius ${ }^{2}$ \\ ${ }^{1,2}$ Faculty of Business Management, Vilnius Gediminas Technical University, \\ Sauletekio al. 11, LT-10223 Vilnius, Lithuania \\ E-mails: ' ${ }^{m}$ ilda.matulaityte-feldhausen@vgtu.lt (corresponding author); ${ }^{2}$ romualdas.ginevicius@vgtu.lt
}

\begin{abstract}
Restoration of independence of Lithuania in 1990 led to highly successful transition from centrally planned economy to market economy within only two decades. New challenges for domestic companies came up, to be a part of internationalization and globalization. It became necessary to develop strategies for national companies to enter international markets and to make the optimal choice of entry mode. The main emphasis is put on the choice between traditional modes of market entry as casual export and new possible entry modes. Typical factors as emigration, intercultural differences etc. are analysed to show how to use domestic market weaknesses to create strengths for entry strategies.
\end{abstract}

Keywords: internationalization, globalization, integration, foreign markets entry modes, challenges, remigration.

JEL Classification: M12; M13; M16.

\section{Introduction}

In 1990, 26 years ago, Lithuania (LT) restored its independence. The country moved highly successfully within shortest time from centrally planned economy (command economy) to market economy with free acting big companies and corporate groups and with small and middle enterprises (SME).

12 years ago (2004) Lithuania joined the European Union and gained free access to 24 markets (Bundesfinanzministerium der Bundesrepublik Deutschland 2016). From then onwards the international markets in Germany, France or Spain started to play the same important role for Lithuanian export companies as the almost "domestic" markets in the neighbourhood of Lithuania: Russia, Belorussia and Ukraine.

In competitiveness rankings - e.g. the Competitiveness Index (GCI) of World Economic Forum (WEF) 2016 from 140 countries - Lithuania achieved the 36th position among 2014-2015 economies. (2014 - 41st place, e.g. Switzerland tops the GCI for the seventh consecutive year). By this criteria, Lithuania is considered as advanced economy and till 2014 was in the group among most competitive economies (Figure 1 graphically illustrates competitive economies by income group).

Average growth rates of the most and least competitive economies, by income group Average growth rate, 2007-14

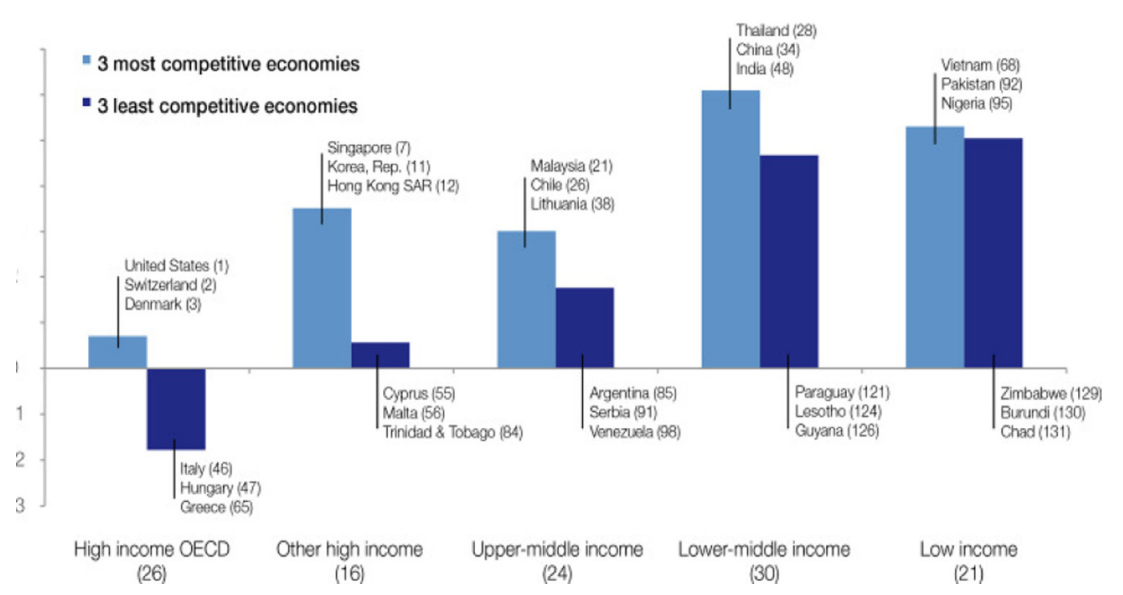

Fig. 1. Competitive economies by income group (Source: WEF 2016) 
Further analysing Lithuanian exports as a percentage of GDP, it is important to show, that in the 10th pillar "Market size" of WEF GCI, Lithuania occupies the 17th position from 186 countries (compare: in the Foreign market size index LT achieves only place 65 ).

Comparing local supplier quantity vs. local supplier quality considerable differences can be seen - place 16 vs. place 30 .

Nowadays Lithuanian SME are faced not only with new challenges to be a part of the internationalization and globalization process but also to become an equal (co-ordinate) global player in the global market. Most international and global players come from the "Old World"-companies with long traditions, which were established e.g. 50 or even 100 years ago (Malik 2013), whereas Lithuanian SME were founded shortly after the fall of the old state-socialistic regime and the introduction of a completely new order with institutions and legal framework. They are representing the "New World" with a company history and tradition of 26 years at most.

All world companies are faced with "the Big Transformation 21 ", where only companies with new, complex and flexible management solutions will be able to survive (Malik 2011). This challenge might be bigger for the world's economies, companies and management than the former transformation of the agrarian society (agricultural society) into industrial society (Malik 2013).

It may be noted that the processes of globalization and global changes, in general, could be perceived and assessed as an essential worldwide transformation, which determines a number of breakings and sallies, important to all the humankind (Melnikas 2014).

Due to modern and omni-accessible modern communications everywhere, from everywhere and almost for everybody and the general globalisation of technologies (Alimienè, Kuvykaite 2004), the processes of globalization, global transformations became more and more rapid. The process of globalisation represents one of the most significant trends that accelerate rapid growth of global corporative strategies.

Therefore, first of all it is necessary to understand the meaning of globalisation or internationalisation. Second, to prepare for international exchange, strategies of national companies to enter international markets and the optimal choice of entry mode are the most important factors for Lithuanian companies to become equal global players, but it has to be stressed that it is necessary to un- derstand the meaning of globalisation and internationalisation.

One of the facets of globalisation is the question whether to increase trade in final goods, intermediate inputs and services or to increase international mobility of capital and labour. Another aspect is that globalisation as such is not a new phenomenon, since the process of investment internationalisation has been taking place over several centuries (McCann, Acs 2009).

\section{Domestic situation in Lithuania}

The last data of the Statistics Lithuania (2016) in Table 1 show the number of companies working abroad controlled by Lithuanian companies.

Table 1. Lithuanian companies busy abroad (Source: Statistics Lithuania 2016)

\begin{tabular}{|c|c|c|c|c|}
\hline & & \begin{tabular}{|c|} 
Persons \\
working \\
abroad in \\
Lithuanian \\
companies
\end{tabular} & $\begin{array}{l}\text { Numbers of } \\
\text { Lithuanian } \\
\text { companies } \\
\text { working } \\
\text { abroad }\end{array}$ & $\begin{array}{l}\text { Turnover } \\
\text { (volume of } \\
\text { sales) } \mid \\
\text { EUR thou- } \\
\text { sand }\end{array}$ \\
\hline \multirow[t]{2}{*}{$\begin{array}{l}\text { Total } \\
\text { foreign } \\
\text { countries }\end{array}$} & 2007 & 25258 & 504 & 2086675 \\
\hline & 2013 & 32963 & 750 & 3748789 \\
\hline
\end{tabular}

Analysing statistic data and surveys of several Lithuanian exporting or expanding companies shows, that Lithuanian companies became active players in the global market during last decade (Statistics Lithuania 2016; Versli Lietuva 2016).

\subsection{International success}

In comparison from 2007 to 2013 turnover grew from 2086675 to 3748789 (EUR thousand). According to the Statistics Lithuania (2016), more than half of the companies active abroad, work in the European Union - 2007296 companies and 2013 already 411 Lithuanian companies in the EU, other countries accounting for 208 (2007) respectively 339 (2013) Lithuanian companies.

Analysing the data of Lithuanian companies active in the EU (Fig. 2) shows clearly that most companies are active in nearby countries like Latvia (162 (2007) and 191 (2013)) and Estonia (42 (2007) and 67 (2013)). These figures illustrate that geographical closeness but also common legal bases by EU law framework play an important role for the choice of settlement country. 


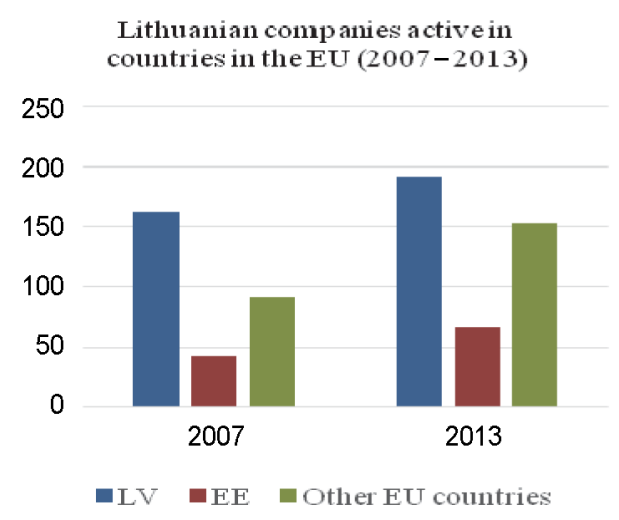

Fig. 2. Lithuanian companies active in countries in the EU, 2007-2013 (Source: Statistics Lithuania 2016)

Analysing the data of Lithuanian companies active in countries outside the EU (Fig. 3) shows that Belorussia is on top of the list (41 (2007) and 105 (2013)), followed by Russia (82 (2007) and 104 (2013)) and Ukraine (68 (2007) and 57 (2013)).

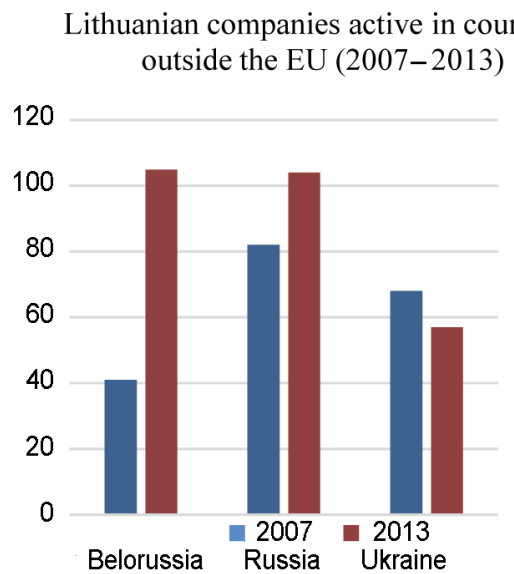

Fig. 3. Lithuanian companies active in countries outside the EU, 2007-2013 (Source: Statistics Lithuania 2016)

Critical factors for the choice of settlement country are hence geographical closeness, cheaper labour force, language knowledge (sometimes no language barrier for market entry).

It has to be stressed that, in addition to the traditional expansion markets for Lithuania, more and more Lithuanian companies start activities in markets with many Lithuanian immigrants (see Table 2). Hence, for the last years the United Kingdom, Ireland and Germany have gained in importance as favourite global markets for Lithuanian companies.

Further analysing the Lithuanian foreign trade, export data and the evaluation according to the Competitiveness Index (GCI) of World Economic Forum (WEF 2016) show that Lithuania holds the 13th position (of 186 states). Figure 4 gives a picture of the development of Lithuanian exports from 2009 to 2015.

The data illustrated in Figure 4 demonstrate that Lithuanian exports grew until 2013 (2009: 5.51 billion of EUR; 2010: 6.84; 2011: 9.61; 2012: 10.3 and 2013: 11.87 billion of EUR). You can explain this by the generally good economic development and other factors.

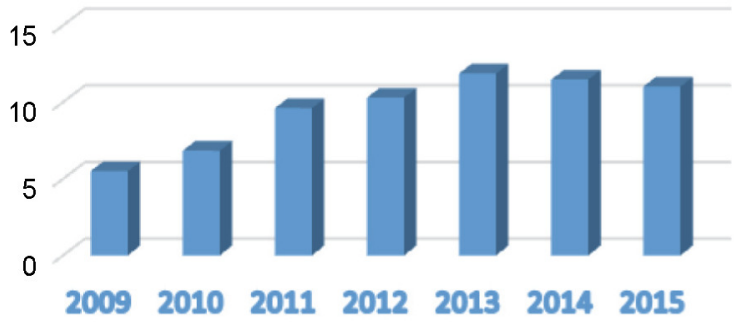

Fig. 4. Lithuanian exports (billions of EUR) (Source: Statistics Lithuania 2016)

But you can see that following 2013/2014 exports declined (11.47 and 11.02 billion of EUR). This can be attributed to the crisis in Ukraine (since the end of 2014) and the following boycott by EU-countries and others of exports to Russia.

Russia as one of the biggest Lithuanian export markets was no longer accessible to Lithuanian companies. To compensate for this decline in exports due to political reasons, companies had to adapt and to realign their exports very quickly.

This challenge has been achieved by Lithuanian SME with partly success. You can mention 12 new export markets that became accessible for Lithuanian exporters since 2015: Brazil, Argentina, Chile, Morocco, Tunisia, Egypt, Hong Kong, Bosnia and Herzegovina, Kosovo etc. Hence all countries have tendency to protect their markets, newmarket-entry to such countries is a rather long and complex process.

In addition to this situation, you have to stress that Lithuanian exporters are one of the few European countries of EU that have the necessary permissions to export to the market of the United States of America.

According to prognostics, economic growth in Lithuania will speed up in 2016 and 2017 because of continuous solid private consumption and the recovering of exports due to more activity on the main Lithuanian export markets (OECD 2015).

\section{Emigration as a challenge for the country but a possibility for business}

Statistics Lithuania (2016) and WEF (2016) figures indicate that Lithuania had a population of 2.9 mio. 
(2'921'262) in the beginning of 2015 (January, 2015). According to forecasts, in 2016 a further number of persons will leave Lithuania (population forecast for the year 2016: 2'888'582).

Table 2. Remigrated Lithuanian citizens and their place of living before (country) (Source: Statistics Lithuania 2016)

\begin{tabular}{l|l|l|l|l|l}
\hline $\begin{array}{l}\text { Former } \\
\text { country } \\
\begin{array}{l}\text { state) of } \\
\text { expatriates }\end{array}\end{array}$ & 2010 & 2011 & 2012 & 2013 & 2014 \\
\cline { 2 - 6 } & & & & & \\
\hline $\begin{array}{l}\text { United } \\
\text { Kingdom }\end{array}$ & 1429 & 6363 & 8160 & 9085 & 9137 \\
\hline Ireland & 606 & 1829 & 2218 & 2161 & 2157 \\
\hline Norway & 246 & 1158 & 1455 & 1736 & 1969 \\
\hline Germany & 260 & 629 & 821 & 1047 & 1129 \\
\hline Spain & 230 & 706 & 875 & 777 & 747 \\
\hline Sweden & 123 & 379 & 431 & 491 & 509 \\
\hline U.S.A. & 292 & 464 & 518 & 490 & 589 \\
\hline Russia & 249 & 385 & 424 & 449 & 449 \\
\hline Denmark & 89 & 382 & 436 & 439 & 493 \\
\hline Holland & 59 & 298 & 385 & 435 & 409 \\
\hline Total & 3583 & 12593 & 15723 & 17083 & 17588 \\
\hline
\end{tabular}

If you compare emigration numbers of 2014 and 2015 , figures show clearly that $10^{\prime} 000$ persons more left Lithuania in 2015 than the year before.

Fact is that since the restoration of independence 26 years ago about $20 \%$ of Lithuania's population left the country. There are no official statistics about the professional qualifications of the emigrants and their relative number. But there is general consensus that not only less qualified workforce but also highly specialised professionals have emigrated from Lithuania. Lithuanian companies had hence continuously to cope with that enormous drain of qualified and highly specialised employees.

It is worth looking at re-emigration into Lithuania. According to latest figures from the State Department of Statistics of Lithuania, 19'528 Lithuanian citizens re-emigrated in 2014. That means that two thirds of immigrants into Lithuania are in fact Lithuanian remigrants.

The majority of them returned back to Lithuania not only with training and education from abroad, new language knowledges and experiences on a foreign employment market but also with equity that they are willing to invest into Lithuanian SME.

Another point is that remigrants have gained new ideas and perspectives about niche-markets or niche-products or new possibilities for exports. This could be an enormous capital for Lithuanian companies that are looking for new export markets or want to develop existing export possibilities.

If emigrants until shortly were considered as lost part of the country's population, entrepreneurs and managers have started to appreciate reemigrants as positive factors and generators for new business. For this reason, remigrants and immigrated Lithuanians (expatriates) should be taken into account as a factor, if a company plans to expand into new foreign markets, especially for human resources planning (Roos 2009).

Table 2 shows the 10 countries from where most re-emigrants into Lithuania came during 2010 to 2013: United Kingdom, Ireland, Norway, Germany, Spain, Sweden, U.S.A., Russia, Denmark and Holland.

These figures are analysed here to prove how to use domestic market weaknesses to create strengths for entry strategies.

\section{Global experience of Lithuanian companies}

SME in general face many barriers (such as the lack of financial and other resources), which prevent them from international development or hinder their involvement in the internationalization process (Kubíčková et al. 2014).

OECD (2009) reported the top barriers to internationalization of SMEs:

- Shortage of working capital to finance exports.

- Limited information to locate/analyze markets.

- Inability to contact potential overseas customers.

- Lack of managerial time, skills and knowledge.

In spite of different efforts of Lithuanian companies to conquer the global and international markets they have rarely had a breakthrough or big success. Mostly, these are companies exporting one product or one part of a product to abroad. Lithuanian products and companies are hardly known in the world.

During the period of July 2015 to January 201622 Lithuanian SME were analysed by the author. They all have international experience and are active on different FM. The following date were analysed:

- Form of the company in Lithuania.

- Field of activities (in domestic market LT/in foreign markets).

- FM in which the companies are active. 
- SWOT (according to information given by the companies).

- Various.

Most companies indicate as external threats classical elements of the direct environment:

- The local authorities.

- The competitors (not only "domestic" competitors in FM, but also Lithuanian companies coming to the same FM), etc.

Majority of companies point to intercultural differences, as one of the most important threat. Of course, there is the language barrier, but also customers in FM who do not want to work with Lithuanian companies (buy, use the services of unknown companies, especially coming from "unknown" Lithuania or Eastern Europe in general). That is why most Lithuanian companies are constrained to work on the global market under a foreign name or to act on the FM as a subcontractor. Even if the LT company works under their own brand, it tries to make an impression on local customers by implementing local managers or even a local CEO.

Investigation of the external environment of Lithuanian companies working abroad results also not only in external barriers, but also in an overview of internal weaknesses.

More and more global Lithuanian players understand that marketing and investments in brand communication are key factors. Without sufficient investments in marketing of the own company name and its brands nobody will know the products and services in the FM, Lithuanian products have no recognition value as such, contrary to Swiss watches or German cars. In addition, success and reputation will not be attributed to the Lithuanian company or brand but to the local player in the FM under which label the LT SME works there (Tarcijonaite 2015).

\section{Necessity of optimal choice of foreign market entry mode for Lithuanian companies}

Under already mentioned circumstances and taking into account several factors for Lithuanian companies' globalisation and necessity for Lithuanian SME for foreign market entry, the most common foreign market (FM) entry mode of Lithuanian companies should be revised. In general, the Lithuanian market should be seen as a small domestic market with limited domestic possibilities.

The home market is to be understood as the home country environment which determines a firm- institutional context. It consists of an opportunity set that is determined by productions factors (e.g., a country's physical infrastructure, labour quality) and institutions (e.g. credibility and effectiveness of a country's bureaucratic infrastructure) (Wan, Hoskisson 2003).

According to WEF Competitiveness Index's (GCI) 11th pillar "Business sophistication" it is clearly visible, that Lithuania occupies even the 16th place from the top in this field. But further analysis of criteria such as "Local supplier quality" (30th place), "Nature of competitive advantage" (64th place), "Control of international distribution" (30th place) or "Extent of marketing (37th place)" indicate that many improvements have to be made for more competitiveness of Lithuanian companies in global markets.

Since firms seek to capture profitable opportunities as defined by their opportunities set, their FM entry mode choice is likely to be contingent on the home country environment (Laufs, Schwens 2014).

For Lithuanian companies, it will be not enough seeking for a place in the global market, for a successful FM entry or becoming an equal global player in the very next future by producing only new products or services. Only investments, investigations and innovations can make Lithuanian companies competitive.

But looking at the newest data of Lithuanian statistics (February, 2016) you can clearly identify, that there are not many products or services with innovation background. E.g. exportations of machinery and mechanical appliances; electrical equipment or mineral products still have top positions on the exportation list, followed by products of the chemical or allied industries, miscellaneous manufactured articles, vegetable products and prepared foodstuffs; beverages, spirits and vinegar or tobacco. It is clearly to be seen that a big part of exportations are of agricultural origin or food products, but hardly any innovative or high-tech products (e.g. Table 3). For this reason, it is quite predictable that without strong investments into innovative products of the future Lithuanian exporters will only satisfy basic needs but will not become important global players on the world market. Positive prognostics alone (e.g. OECD) will not change this situation.

The foreign market or host market (host country) determinates the formal (e.g. political risks) and informal (e.g., culture) institutional context with which a firm must deal with in a foreign country. These conditions may affect the company's foreign market entry mode choice. The international EM decision is also considered as one of the most critical decisions in the internationalization process of the firm. (Morschett et al. 2010). 
This decision concerns the choice of governance form for foreign operations among exporting, contractual modes, joint ventures and wholly owned subsidiaries (Ji, Dimitratos 2013). Since this decision involves the consideration of risk, return, control and commitment, its implication for performance are significant (Anderson, Gatignon 1986).

Table 3. Exports and imports by BEC (Source: Statistics Lithuania 2016)

\begin{tabular}{l|c|c}
\hline \multicolumn{2}{c|}{ Per cent BEC } & $\begin{array}{c}\text { January - } \\
\text { December, } \\
2015\end{array}$ \\
\hline \multicolumn{2}{c}{ exports } & imports \\
\hline Total & $\mathbf{1 0 0}$ & $\mathbf{1 0 0}$ \\
\hline Capital goods & 11.9 & 15.3 \\
\hline Intermediate goods & 51.3 & 56.9 \\
\hline Consumption goods & 30.4 & 24.6 \\
\hline Motor spirit & 5.0 & 0.2 \\
\hline Passenger motor cars & 1.0 & 3.0 \\
\hline Others & 0.3 & 0.1 \\
\hline
\end{tabular}

Note: BEC - Broad Economic Categories Classification.

In general, companies can expand into foreign markets by using the following mechanisms (Michalski 2015).

- Exporting:

(1) Direct exporting using a domestic-based export department or

(2) Export sales representatives (sent abroad or already existing abroad).

- Direct investment:

(1) Creating a new own company or participation in existing company activities vs.

(2) Establishing a Joint Venture (JV).

- Foreign-based distributors/agents with exclusive rights to represent the company.

Czinkota an Ronkainen (2001); Michalski (2015) Figure 5 shows that the enterprises choose between three forms of market development in the international area:

- I Passive participation.

- II Entry into contact.

- III Taking an international position.

FM entry modes are the most researched field in international management (Alon 2004).

A number of FM characteristics can affect the choice of market servicing modes. The commonly examined characteristics are attractiveness and market size. Laufs and Schwens (2014) analyses industry environment, the country risk, location and legal rules regarding EM.

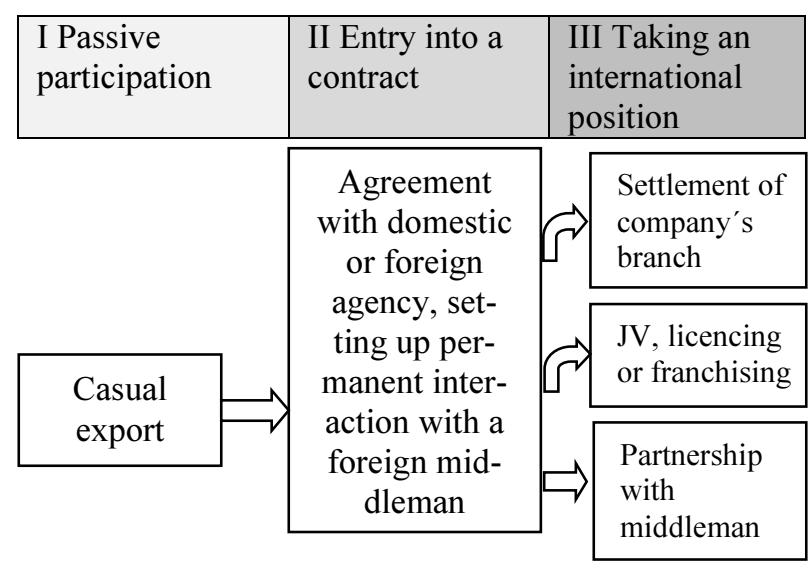

Fig. 5. Enterprise involvement into international exchange (Source: Michalski 2015)

Among other criteria, not only physic distance which defines "the sum of factors preventing the flow of information to and from the market" (Laufs, Schwens 2014; Johanson, Vahlne 1977; Chung, Enderwick 2001; Ji, Dimitratos 2013) has a high importance for Lithuanian companies on foreign market entry mode. Also cultural distance influences the entry mode decision (Chang et al. 2012).

Unfortunately, Lithuanian companies consider this factor much too seldom and intercultural differences are not taken into account when formulating the company strategy.

Companies get very often a false picture of a FM because of omni-information access without detailed and profound research about the relevance of information found.

E.g. the Scandinavian countries: Norway, Sweden, Denmark and Finland import from Lithuania more than two times more than the biggest former Lithuanian host country Russia. That is why Scandinavian countries can already be considered as replacement for the "lost" FM in the East. But labour standards in Scandinavia and Lithuania are completely different, that is why expansion into these countries takes much time (half a year, one year or even longer). Lithuanian business promoting agency "Versli Lietuva" (2016) suggests to take into account this change of mind-set into the strategies of companies. Even the attitude towards profit must be thought over due to cultural differences. Companies experiences in Western countries will give credits of trust to the companies. Whereas it is recommended not to mention Scandinavian experiences in the Russian market (especially not a Finnish partner).

Another example is the Swiss market. More and more Lithuanian companies show interest in this market to cooperate with domestic companies, either by joint ventures or exporting. Since many 
Lithuanian SME have made relatively wide and long experiences with the German FM, they consider Switzerland simply as another "Germanspeaking country". Lacking experience, badly knowing the Swiss reality and not preparing themselves correctly, they do not take into account the four language regions (e.g. three official languages) and their practical influence on doing business. The necessary translations for the authorities may take longer as expected and the daily business correspondence should be adapted to local business partners. These details in culture and geography are critical for success and should be integrated into the strategy formulating process.

It has to be added that the market entry of Lithuanian companies very often fails because of these "unimportant" cultural or other minor factors. The most effective business-promoting agency in Lithuania "Versli Lietuva" - established to support the establishment and development of competitive businesses in Lithuania and to foster the country's exports by facilitating cooperation with foreign partners' networks and providing quality training, consultancy, market analysis, and business-partner search services - gives some practical advises which should be implemented into the companies' long-term strategy for expansion.

\subsection{Franchising as a smart alternative for Lithuanian SME to direct exporting}

"Versli Lietuva" registers over 1291 export enterprises from Lithuania (February 2016) in its Lithuanian Exporters Database (EDB). EDB is a tool designed for foreign companies that are looking for a reliable partner in Lithuania. EDB contains information about Lithuanian manufacturers and service providers from various business sectors.

If you further analyse the registered SME in EDB, you will notice that only $1.3 \%$ of all registered business entities in LT (99'200 in January 2016) are registered in the EDB.

That clearly shows that Lithuanian SME should use other methods to sell their products or services in foreign markets - franchising could be a solution; if they do not already use it.

A franchise agreement is defined as a contractual arrangement between two independent firms, whereby the franchisee pays the franchisor for the right to sell the franchisor's product and/or the right to use his trademark at a given place and for a certain period of time (Lafontaine 1992).

The franchisor, the parent company, develops a product or service for sale by the franchisees that market it in a particular location. Typically, a franchisee pays a lump sum fee for the right to market the product and also pays royalties, such as a percentage of sales. In addition, the franchisee may purchase specific inputs from the franchisor (Norton 1988).

Although franchised enterprises, which typically operate in low-technology sectors of the economy, receive less attention than entrepreneurial ventures in high-tech industries, such as the Internet or biotechnology, entrepreneurship through franchising accounts for a large, and growing, share of business in both retail sales and the provision of services (Sorenson, Sørensen 2001).

Regarding the situation in LT, franchising is still not a very popular business development form, and very poorly extended, while e.g. France, Germany and UK are the countries with largest franchising business markets in EU (Kavaliauske, Vaiginienè 2011).

\section{Conclusions}

Considering casual export as the most common entry mode of Lithuanian SME a systematic approach to foreign market entry modes could improve the performance and competitiveness of Lithuanian SME in foreign markets.

Rather than "learning by doing" while entering new foreign markets companies should use tools to make optimal choices of entry modes depending on their strategic set and their competences.

An additional factor of success can be the well-thought use remigrated Lithuanians with their knowledge and experience about a foreign market in particular. They could be not only competent contact persons to learn about the foreign market and possible product and market niches that might be available to them but also as a bridge to other countries with a wide net of foreign market contacts and new opportunities at hand.

Until now, LT was among the countries with relatively well qualified workforce and low production costs. But until the end of 2020, according to forecasts, the official minimum wage will rise to 1050 EUR before taxes. Production costs will simply be to high compared to other countries such as Ukraine, Moldova and other countries in the Balkan region. These countries will be able to deliver the same quality for lower prices.

Because of these trends, LT companies should choose very thoroughly the long-term FM entry mode. In addition, they should not bet on exporting agricultural or food products but foster on valueadded services and innovative high-tech products 
that they have still to create to offer them on the global market.

\section{References}

Alimienè, M.; Kuvikaite, R. 2004. Internacionalizacijos teorijų ribos: gimusių globalių imonių fenomenas [The limits of traditional internationalization theories: phenomenon of the born globals], Management of Organizations: Systematic Research 30: $7-20$.

Alon, I. 2004. Global franchising and development in emerging and transitioning markets, Journal of Macromarketing 24(2): 156-167. http://dx.doi.org/10.1177/0276146704269320

Anderson, E.; Gatignon, H. 1986. Modes of foreign entry: a transaction cost analysis and propositions, Journal of international business studies 17(3): 126 [online], [cited 1 February 2016]. Available from Internet: http://www.jstor.org/stable/http:// dx.doi.org/10.1057/palgrave.jibs.8490432

Chang, Y. C.; Kao, M. S.; Kuo, A.; Chiu, C. F. 2012. How cultural distance influences entry mode choice: the contingent role of host country's governance quality, Journal of Business Research 65(8): 1160-1170. http://dx.doi.org/10.1016/j.jbusres.2011.07.033

Chung, H. F.; Enderwick, P. 2001. An investigation of market entry strategy selection: exporting vs foreign direct investment modes - a home-host country scenario, Asia Pacific Journal of Management 18(4): 443-460. http://dx.doi.org/10.1023/A:1012871225166

Czinkota, M. R.; Ronkainen, I. A. 2001. International marketing. Harcourt College Publishers.

Bundesfinanzministerium der Bundesrepublik Deutschland. 2016. Die Entwicklung der EU [The development of EU] [online], [cited 18 February 2016]. Available from Internet:

http://www.bundesfinanzministerium.de/ (in German).

Ji, J.; Dimitratos, J. 2013. An empirical investigation into international entry mode decision-making effectiveness, International Business Review 22(6): 994-1007.

http://dx.doi.org/10.1016/j.ibusrev.2013.02.008

Johanson, J.; Vahlne, J. E. 1977. The internationalization process of the firma model of knowledge development and increasing foreign market commitments, Journal of International Business Studies 8(1): 23-32. http://dx.doi.org/10.1057/palgrave.jibs.8490676

Kavaliauskè, M.; Vaiginienè, E. 2011. Franchise business development model: theoretical considerations, Business: Theory and Practice 12(4): 323331.

Kubíčková, L.; Votoupalová, M.; Toulová, M. 2014. Key motives for internationalization process of small and medium-sized enterprises, Procedia Economics and Finance 12: 319-328. http://dx.doi.org/10.1016/S2212-5671(14)00351-7

Lafontaine, F. 1992. Agency theory and franchising: some empirical results, The Rand Journal of Economics 7(1): 263-283.

http://dx.doi.org/10.2307/2555988

Laufs, K.; Schwens, C. 2014. Foreign market entry mode choice of small and medium-sized enterprises: a systematic review and future research agenda, International Business Review 23(6): 1109-1126. http://dx.doi.org/10.1016/j.ibusrev.2014.03.006

Malik, F. 2011. Management: the essence of the craft. Frankfurt/New York: Campus Verlag.

Malik, F. 2013. Management: das a und o des handwerks [Management: the essence of the craft]. Frankfurt/New York: Campus Verlag (in German).

McCann, P.; Acs, Z. J. 2009. Globalisation: countries, cities and multinationals, Chapeter 19, in Global Entrepreneurship, Institutions and Incentives: The Mason Years. Edward Elgar Publishing, 371-386.

Melnikas, B. 2014. Global transformations: variety, phenomena and regularities, holistic approach, in $8^{\text {th }}$ International Scientific Conference "Business and Management 2014”, 15-16 May 2014, Vilnius, Lithuania.

Michalski, E. 2015. Foreign market entry strategy, Acta Scientiarum Polonorum Oeconomia 14(2): 107117.

Morschett, D.; Schramm-Klein, H.; Swoboda, B. 2010. Decades of research on market entry modes: what do we really know about external antecedents of entry mode choice?, Journal of International Management 16(1): 60-77. http://dx.doi.org/10.1016/j.intman.2009.09.002

Norton, S. W. 1988. An empirical look at franchising as an organizational form, Journal of Business 61(2): 197-218. http://dx.doi.org/10.1086/296428

OECD. 2009. Top barriers and drivers to SME internationalisation [online]. Report by the OECD working party on SMEs and entrepreneurship, OECD [cited 2 February 2016]. Available from Internet: http://www.oecd.org/cfe/smes/43357832.pdf

OECD. 2015. Litauen, in OECD Wirtschaftsausblick. OECD [Lithuania, from OECD Economic Outlook] (in German).

http://dx.doi.org/10.1787/eco_outlook-v2015-231-de

Roos, B. 2009. Planung von markteintritten in Russland: Disertation [A Planning of an entry into the Russian Market]. University of Fribourg, Fribourg (in German).

Sorenson, O.; Sørensen, J. B. 2001. Finding the right mix: franchising, organizational learning, and chain performance, Strategic Management Journal 22(6-7): 713-724. http://dx.doi.org/10.1002/smj.185 
Statistics Lithuania. 2016. Business statistics [online]. Official Statistics Portal of the Government of the Republic of Lithuania [cited 14 February 2016]. Available from Internet: http://osp.stat.gov.lt/en/temines-lenteles46

Tarcijonaite, M. 2015. Artèjame prie lūžio taško - ką pasirinkti [Which way should we choose in the next future], Verslo žinios 183(4456): 11 (in Lithuanian).

Versli Lietuva [online]. 2016 [cited 14 February 2016]. Available from Internet: http://www.enterpriselithuania.com/en/

Wan, W. P.; Hoskisson, R. E. 2003. Home country environments, corporate diversification strategies, and firm performance, Academy of Management Journal 46(1): 27-45. http://dx.doi.org/10.2307/30040674

WEF. 2016. The Global Competitiveness Report 20152016 [online], [cited 29 January 2016]. Available from Internet: http://reports.weforum.org/globalcompetitiveness-report-2015-2016/economies/\# indexId $=\mathrm{GCI} \&$ economy $=\mathrm{LTU}$ 